\title{
Heart transplantation in atrial switch and in congenitally corrected transposition of the great arteries
}

\author{
E Delmo Walter ${ }^{*}$, R Hetzer \\ From 23rd World Congress of the World Society of Cardio-Thoracic Surgeons \\ Split, Croatia. 12-15 September 2013
}

\section{Background}

Patients with congenitally corrected transposition of the great arteries (ccTGA) and those who underwent atrial switch eventually face systemic ventricular failure due to deterioration of the morphological and structural function. Heart transplantation is at present one of the two best available options. We report our institutional experience of heart transplantation in this group, with emphasis on surgical techniques, risk factors and long-term outcome.

\section{Methods}

Between 1992 and 2011, 21 patients (mean age: 21.68 \pm 6 , range 1.4-27 years) with TGA (L-TGA $=7$; $\mathrm{D}-\mathrm{TGA}=8$; ccTGA $=6$ ) underwent heart transplantation for endstage heart failure. Previous operations were Senning procedure $(n=8)$, Mustard operation $(n=5)$, double switch $(\mathrm{n}=2)$, arterial switch $(\mathrm{n}=2)$, Fontan operation $(\mathrm{n}=1)$, mitral and tricuspid valve replacement $(\mathrm{n}=1)$ and palliative shunting $(\mathrm{n}=2)$. Six patients had pulmonary hypertension.

\section{Results}

Previous surgeries, alterations in the atrial anatomy, other anatomic abnormalities and the presence of intra-atrial conduits required technical modifications in harvesting and implantation. Postoperative morbidity was hemorrhage which was easily controlled. Cause of early mortality was severe pulmonary hypertension. Late mortality was due to graft dysfunction. At a mean follow-up of 5.9 years (1-22.8 years), overall survival rates are $78.6 \%, 57.1 \%$ and $42.8 \%$, at 1,5 and 20 years.

\footnotetext{
* Correspondence: delmo-walter@dhzb.de

Cardiothoracic Surgery, Deutsches Herzzentrum Berlin, Berlin, Germany
}

\section{Conclusions}

Previous operations did not produce major technical problems in heart transplantation. Pulmonary hypertension is the only risk factor for mortality. The long-term survival rate is highly satisfactory.

Published: 11 September 2013

doi:10.1186/1749-8090-8-S1-0305

Cite this article as: Delmo Walter and Hetzer: Heart transplantation in atrial switch and in congenitally corrected transposition of the great arteries. Journal of Cardiothoracic Surgery 2013 8(Suppl 1):0305.
Submit your next manuscript to BioMed Central and take full advantage of:

- Convenient online submission

- Thorough peer review

- No space constraints or color figure charges

- Immediate publication on acceptance

- Inclusion in PubMed, CAS, Scopus and Google Scholar

- Research which is freely available for redistribution
() Biomed Central 